Protein measurement with the Folin phenol reagent. J. Biol. Chem., 193: 265 (1951).

8. Mandel, I. D., Kutcher, A., Denning, C. R., Thompson, R. H., and Zegarelli, E. V.: Salivary studies in cystic fibrosis. Amer. J. Dis. Child., 113: 431 (1967).

9. Mandel, I. D., Thompson, R. H., Wotman, S., Taubman, H., Kutcher, A. H., Zegarelli, E. V., Denning, C. R., Botwick, J. T., and Fahn, B. S.: Parotid saliva in cystic fibrosis. Amer. J. Dis. Child., 110: 646 (1965).

10. Mangos, J. A., and McSherry, N. R.: Sodium transport: Inhibitory factor in sweat of patients with cystic fibrosis. Science, 158: 135 (1967).

11. Mangos, J. A., and McSherry, N. R.: Studies on the mechanism of inhibition of sodium transport in cystic fibrosis of the pancreas. Pediat. Res., 2: 378 (1968).

12. Mangos, J. A., McSherry, N. R., and Benke, P. J.: A sodium transport inhibitory factor in the saliva of patients with cystic fibrosis of the pancreas. Pediat. Res., 1: 436 (1967).

13. Schneyer, L. H.: Collection of separate submaxillary and sublingual salivas in man. J. Dent. Res., 33: 683 (1954).

14. Weisman, U. N., Boat, T. F., and Di Sant'Agnese, P. A.: Elevated sodium chloride in saliva. Lancet, $i$ : $510(1972)$.

15. Samples were centrifuged for $5 \mathrm{sec}$ at $15,000 \mathrm{rpm}$ in a Beckman microfuge, model 152 .

Copyright $(9) 1974$ International Pediatric Research Foundation, Inc.
16. Obtained from Sprague-Dawley, Madison, Wisc.

17. Made by heating polyethylene tubing (Clay Adams PE 100) and drawing it out to the desired diameter.

18. Beckman no. 314326, Beckman Instruments, Palo Alto, Calif.

19. A standard heated rat operating table built at the University of Wisconsin machine shop was used.

20. Yellow Springs Instrument Co, Yellow Springs, Ohio. Telethermometer, model no. $41 \mathrm{TA}$, and internal probe no. 401 .

21. Flame photometer model 143, Instrumentation Laboratory, Inc., Lexington, Mass.

22. The sublingual salivas reported in this table were stored at $-20^{\circ}$ for 10 days or less before they were used; therefore they are not included in the data in Table 1.

23. Informed consent was obtained for all subjects in this study.

24. The authors wish to thank Dr. John A. Mangos and Mrs. Nona R. McSherry for their helpful suggestions and assistance.

25. This work was supported by the United States Public Health Service Grant no. AM-08305; the Cystic Fibrosis Foundation, Cleveland Chapter, via the Health Fund of Cleveland.

26. Requests for reprints should be addressed to: L. W. Matthews, M.D., Department of Pediatrics, Case Western Reserve University, Cleveland, Ohio 44106 (USA).

27. Accepted for publication June 24, 1974.

Printed in U.S.A.

Pediat. Res. 8: 865-870 (1974)

Arylsulfatase A genetic disorder I-cell disease

\title{
Studies on the Pathogenetic Mechanism of I-Cell Disease in Cultured Fibroblasts
}

\author{
U. N. WIESMANN ${ }^{(26)}$ AND N. N. HERSCHKOWITZ
}

Department of Pediatrics, Divisions of Cellbiology and Neurochemistry, University of Berne, Berne, Switzerland

\section{Extract}

A marked intracellular reduction of six lysosomal enzymes could be demonstrated in fibroblasts from four different patients with mucolipidosis type II or I-cell disease. In contrast to that finding, conditioned media from the same cells contained a $2-10$-fold increase of the activities of five lysosomal enzymes over control values. In obligate heterozygotes elevated lysosomal enzyme activities in the conditioned media were also found, but normal enzyme activities were measured intracellularly. A functional impairment of the lysosomal degradation of $\left({ }^{35} \mathrm{SO}_{4}\right)$ mucopolysaccharide (MPS) and of $\left({ }^{3}\right.$ S)-sulfatide could be shown in the I-cell fibroblasts, as a consequence of decreased enzyme activities.

Substitution of the enzyme-deficient cells with normal urinary arylsulfatase $A$ and with mucopolysaccharide degrading factors from normal conditioned media was possible, but failed when urine from patients or conditioned media factors from the I-cell fibroblasts were used.

\section{Speculation}

Genetic disorders of lysosomal functions can be caused not only by lack of synthesis or by a structural defect of a lysosomal enzyme, but also by a genetically determined loss of enzyme into the extracellular fluid. These lysosomal enzymes are functionally abnormal only insofar as they cannot be retained within the cells, and, furthermore, once they are outside of the cells, they can not re-enter the cells by pinocy tosis as can normal enzymes.

Mucolipidosis II or inclusion cell (I-cell) disease is an inherited condition clinically resembling a classic mucopolysaccharidosis, without the typical excessive excretion of mucopolysaccharides in urine (15). Highly increased levels of lysosomal enzyme activities are found in the extracellular fluids of the patients $(17,21,22)$. In cultured fibroblasts from patients typical granular cytoplasmic inclusions are seen, hence, the name I-cell disease (10). A multiple deficiency of lysosomal enzymes has been demonstrated in cultured I-cell fibroblasts $(10,11)$. In a preliminary report (18) we have shown that increased lysosomal enzyme activities also can be measured in conditioned culture medium of I-cell fibroblasts. We have now confirmed these findings for a number of different I-cell lines from patients with mucolipidosis II and have studied the impact of the multiple enzyme deficiency on lysosomal function in the I-cell fibroblasts. Furthermore, the 
effect of the substitution of deficient lysosomal enzymes on the degradation defects was analyzed. Finally, stimulated by the paper of Hickman and Neufeld (9), who postulate an impaired uptake of lysosomal enzymes via defective recognition sites, the uptake of lysosomal arylsulfatase A (EC. 3.1.6.1) from I-cell patient into enzyme-deficient cells was studied.

\section{MATERIAL AND METHODS}

\section{TISSUE CULTURE}

Skin fibroblasts from four patients with mucolipidosis II (24) were grown in Eagle's minimal essential medium supplemented with $10 \%$ fetal calf serum as described previously (20).

\section{ENZYME DETERMINATIONS}

For determination of enzymes the cells were grown to confluency, trypsinized with $0.25 \%$ trypsin, washed once in $0.9 \%$ saline, and sonicated two times for $30 \mathrm{sec}$ at $0^{\circ}$ in a Branson Ultrasonicator. The culture medium was not sonicated but was dialyzed overnight against $0.1 \mathrm{M} \mathrm{Na}$ acetate buffer, pH 5.7, before enzyme determination.

Arylsulfatase $A$ and $B$ were determined according to the method of Baum et al. (2). Acid phosphatase was assayed according to the method of Baggiolini et al. (1). All other lysosomal enzymes were measured according to the method of Van Hoof and Hers (16). Malate dehydrogenase (MDH) and lactic acid dehydrogenase (LDH) were estimated following the methods of Bergmeyer (3). Heat inactivation of arylsulfatase A was measured after incubating the cell homogenates at $60^{\circ}$ for $30 \mathrm{~min}$. Heat inactivation of $N$-acetyl- $\beta$-galactosaminidase was performed by heating the homogenates at $55^{\circ}$ for $30 \mathrm{~min}$. Proteins were determined according to the Lowry method (12).

\section{PREPARATION OF ARYLSULFATASE A AND OF CORRECTIVE FACTORS}

Partially purified arylsulfatase A was prepared from normal human male urine by ammonium sulfate precipitation as described previously (20). Conditioned culture medium concentrates were prepared according to the method of Fratantoni et al. (6).

\section{PREPARATION OF $\left({ }^{35}\right.$ S)SULFATIDE}

$\left({ }^{35} \mathrm{~S}\right)$ Sulfatide was prepared from rat brain as described previously $(8,20)$. The specific activity was $350 \mu \mathrm{Ci} / \mathrm{mmol}$.

\section{RESULTS}

\section{INTRACELLULAR ACTIVITY OF LYSOSOMAL ENZYMES}

The intracellular activity of six lysosomal enzymes was markedly reduced in all four I-cell fibroblast strains as shown in Table 1. The activity of acid phosphatase, however, was normal. Nonlysosomal enzymes like MDH, a mitochondrial enzyme, and LDH, a cytoplasmic enzyme marker, were normal. Mixing of cell homogenates of normal and I-cell fibroblasts gave intermediate enzyme activities. Fibroblasts from obligate heterozygotes (parents of patient $G G$ ) showed normal activities of the lysosomal enzymes.

\section{EXTRACELLULAR LYSOSOMAL ENZYME ACTIVITIES IN CONDITIONED CULTURE MEDIA}

Lysosomal enzyme activities have previously been found elevated in "used" (conditioned) culture medium in which fibroblasts from patient $G G$ had been growing for 3 days (18). This preliminary finding could be confirmed in the culture media obtained from three more I-cell fibroblast lines as shown in Table 2. No increase in the activity of nonlysosomal enzymes (LDH and MDH) could be detected in the media of these cells. Fibroblast medium from the parents of patient $G G$ also showed elevated lysosomal enzyme activities (Table 2).

\section{FUNCTIONAL DEFECTS OF THE LYSOSOMAL DEGRADATION}

Degradation of $\left({ }^{35} \mathrm{SO}_{4}\right)$ MPS. In normal cells the half-life of the degradation of ${ }^{35} \mathrm{SO}_{4}$-labeled MPS was estimated to be 4-5 $\mathrm{hr}$. In the fibroblasts of the patients with mucolipidosis II the half-life was $24-36 \mathrm{hr}$. In contrast, the rate of disappearance of the label from cells of a Hurler patient yielded a half-life of more than $48 \mathrm{hr}$ (Fig. 1).

Degradation of $\left({ }^{35} S\right)$ Sulfatide. In the presence of $\left({ }^{35} \mathrm{~S}\right)$ sulfatide in the culture medium for 3 days this compound accumulated intracellularly in I-cell fibroblasts about twice the amount in normal cells. In metachromatic leucodystrophy (MLD) fibroblasts the accumulation was up to 3 times the normal values. At the same time the degradation of $\left({ }^{35} \mathrm{~S}\right)$ sulfatide to free extracellular ${ }^{35} \mathrm{SO}_{4}$ in I-cell fibroblasts proceeded only at about $30 \%$ of normal but still at higher rates than in MLD fibroblasts (Fig. 2).

Substitution of Arylsulfatase $A$ in I-cell and in $M L D$ Fibroblasts. Arylsulfatase A preparation from normal urine was added in increasing amounts to the medium in which fibroblasts from I-cell or from MLD patients were growing (Fig. 3). Addition of extracellular enzyme resulted in nearly linear dose-dependent increase in intracellular arylsulfatase A in both enzyme-deficient cell lines. However, when arylsulfatase A activity prepared from urine of mucolipidosis II patients was used, no such substitution of intracellular enzyme

Table 1. Lysosomal enzymes (mean $\pm S D$ ) in fibroblasts ${ }^{1}$

\begin{tabular}{|c|c|c|c|c|c|c|c|c|}
\hline I-cell fibroblasts & ND & Aryl A & Aryl B & NAGA & NAGU & $\alpha$-Fuc & $\beta$-Gal & Acid P-ase \\
\hline 1. $B K$ & 6 & $0.14 \pm 0.03$ & $0.34 \pm 0.16$ & $0.93 \pm 0.16$ & $2.17 \pm 0.5$ & $0.06 \pm 0.03$ & $0.75 \pm 0.08$ & 0.5 \\
\hline 2. $L B$ & 7 & $0.12 \pm 0.08$ & $0.12 \pm 0.08$ & $1.50 \pm 0.67$ & $3.67 \pm 1.5$ & 0.00 & $0.41 \pm 0.16$ & 0.34 \\
\hline 3. $L G$ & 5 & $0.16 \pm 0.03$ & $0.22 \pm 0.12$ & $0.75 \pm 0.50$ & $2.33 \pm 1.0$ & $0.1 \pm 0.03$ & $0.16 \pm 0.08$ & 0.58 \\
\hline 4. $G G$ & 13 & $0.33 \pm 0.16$ & $0.25 \pm 0.10$ & $0.87 \pm 0.50$ & $3.0 \pm 0.33$ & $0.15 \pm 0.06$ & $0.20 \pm 0.01$ & 0.37 \\
\hline \multicolumn{9}{|l|}{ Parents of $G G$} \\
\hline Mother & 1 & 5.67 & 3.86 & $16.00 \pm 2.0$ & 52.17 & 0.42 & 4.17 & 0.5 \\
\hline Father & 1 & 6.43 & 2.60 & 10.5 & 56.67 & 1.0 & 3.33 & 0.37 \\
\hline \multicolumn{9}{|l|}{ Normal fibroblasts } \\
\hline$N=6$ cell lines & & $7.12 \pm 1.75$ & $2.43 \pm 1.0$ & $14.8 \pm 2.67$ & $41.67 \pm 15$ & $0.83 \pm 0.16$ & $4.3 \pm 2.5$ & $0.42 \pm 0.08$ \\
\hline
\end{tabular}

${ }^{1}$ Aryl A, aryl B: arylsulfatase A, B: NAGA: $N$-acetyl- $\beta$-galactosaminidase; NAGU $=N$-acetyl- $\beta$-glucosaminidase; $\alpha$-Fuc: $\alpha$-fucosidase; $\beta$-Gal: $\beta$-galactosidase; Acid P-ase: acid phosphatase; ND: number of determinations. All enzyme activities are expressed as millimicromoles of substrate cleaved per minute and per milligram of protein. 
Table 2. Lysosomal enzymes in culture medium ${ }^{1}$

\begin{tabular}{|c|c|c|c|c|c|c|}
\hline I-cell fibroblasts & ND & Aryl A & Aryl B & NAGA & NAGU & $\alpha$-Fuc \\
\hline 1. $B K$ & 5 & $0.5 \pm 0.13$ & $0.3 \pm 0.08$ & $3.5 \pm 1.5$ & $11.25 \pm 5.0$ & 0.0 \\
\hline 2. $L B$ & 6 & $0.42 \pm 0.15$ & $0.26 \pm 0.06$ & $3.0 \pm 1.8$ & $15.33 \pm 3.5$ & $0.1 \pm 0.1$ \\
\hline 4. $G G$ & 10 & $0.36 \pm 0.16$ & $0.4 \pm 0.06$ & $5.67 \pm 2.0$ & $12.0 \pm 4.0$ & $0.27 \pm 0.1$ \\
\hline \multicolumn{7}{|l|}{ Parents of $G G$} \\
\hline Mother & & 0.30 & 0.26 & 2.8 & 8.5 & 0.0 \\
\hline \multicolumn{7}{|l|}{$\begin{array}{l}\text { Normal fibroblasts } \\
\mathrm{N}=6 \text { cell lines }\end{array}$} \\
\hline & & $0.03 \pm 0.008$ & $0.02 \pm 0.01$ & $1.6 \pm 0.48$ & $5.0 \pm 2.5$ & 0.0 \\
\hline
\end{tabular}

${ }^{1}$ Aryl A, aryl B: arylsulfatase A, B: NAGA: $N$-acetyl- $\beta$-galactosaminidase; NAGU: $N$-a cetyl- $\beta$-glucosaminidase; $\alpha$-Fuc: $\alpha$-fucosidase; ND: number of determinations. Enzyme activity was measured in an aliquot of the conditioned medium. The activity in an aliquot of unconditioned medium was substrated from this value. The total activity was calculated from the net activity of the aliquot for the total volume of the medium (15 ml) and corrected for the protein of the cells of the culture from which the media had been harvested.

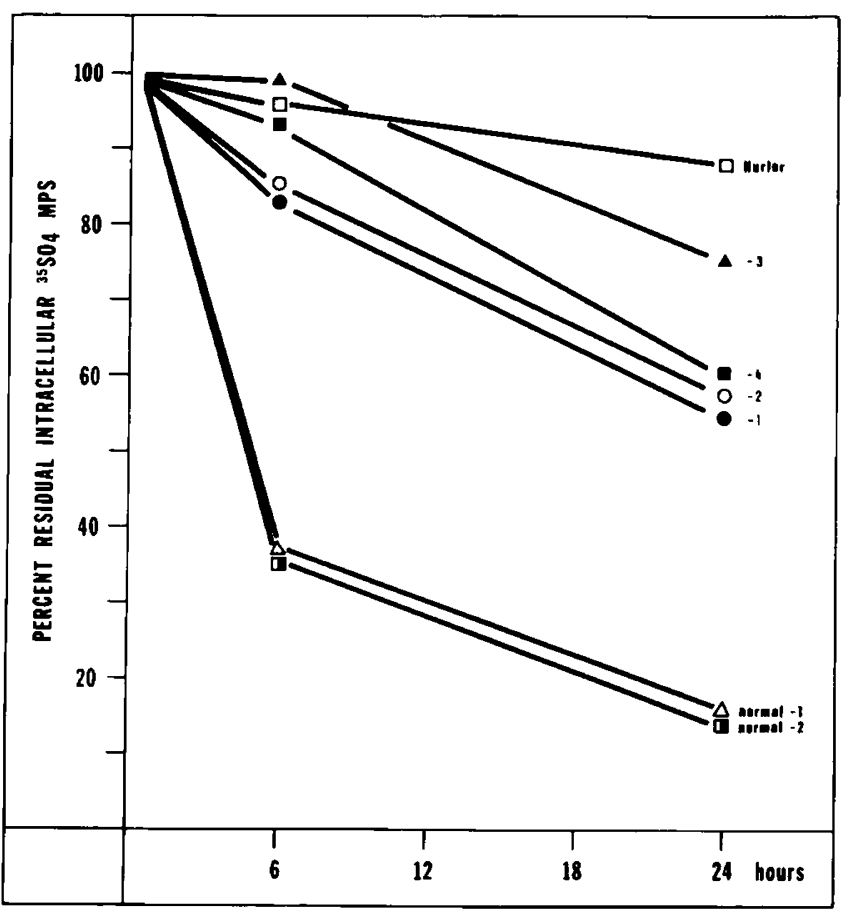

Fig. 1. Degradation of intracellular $\left({ }^{35} \mathrm{SO}_{4}\right)$-mucopolysaccharide(MPS) in fibroblasts. Fibroblasts were prelabeled for $72 \mathrm{hr}$ with $5 \mu \mathrm{Ci}$ carrier-free ${ }^{35} \mathrm{SO}_{4} / \mathrm{ml}$ medium in $100-\mathrm{mm}$ plastic petri dishes. Then the medium was removed, the cells were washed once in situ with saline, and fresh medium was supplied to all plates except for the ones that were analyzed immediately (zero time value). Plates were harvested after 6 and after $24 \mathrm{hr}$, respectively. The intracellular $\left({ }^{35} \mathrm{SO}_{4}\right) \mathrm{MPS}$ was expressed as percentage of the values at zero time. 1, 2, 3, 4: I-cell fibroblasts (numbers correspond to those in Tables 1 and 2).

activity was observed. Arylsulfatase A prepared from obligate heterozygotes was less active in the substitution of enzymedeficient cells than normal. In both I-cell and MLD fibroblasts the substituted normal arylsulfatase $A$ remained active for the same period of time. The half-life was estimated to be 10--14 days.

Substitution of MPS-degrading Factors in I-Cell and in Fibroblasts from Mucopolysaccharidoses. Fibroblasts from different types of mucopolysaccharidoses show a defect in the degradation of sulfated MPS (6). This could be demonstrated by the greatly retarded disappearance of $\left({ }^{35} \mathrm{SO}_{4}\right)$ MPS from

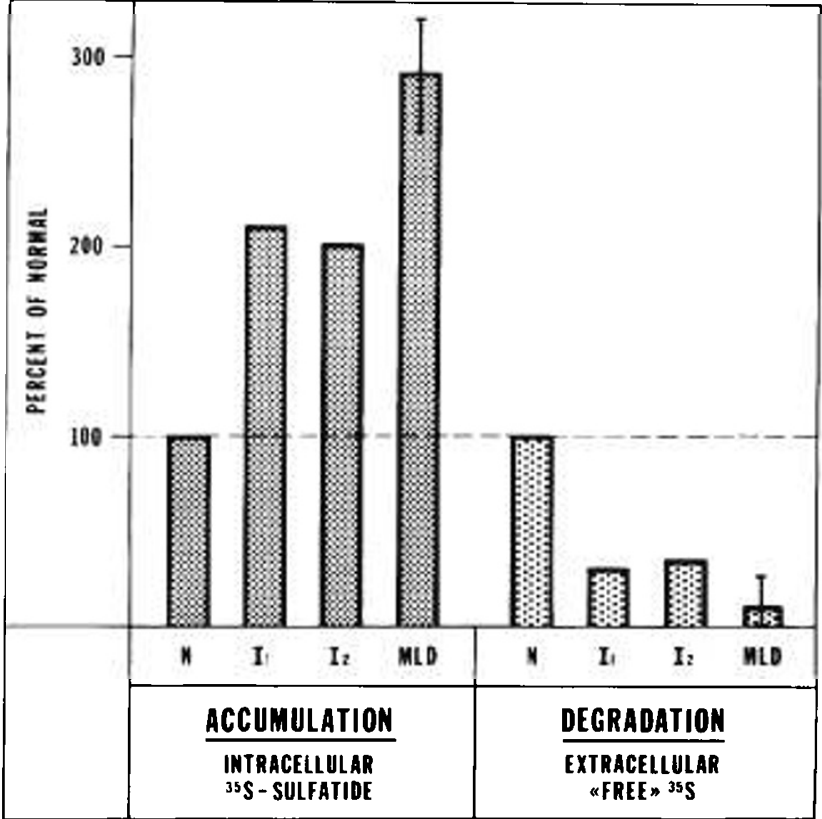

Fig. 2. Degradation of $\left({ }^{35} \mathrm{~S}\right)$ sulfatide. $\left({ }^{35} \mathrm{~S}\right)$ Sulfatide was solubilized in $0.5 \mathrm{~N} \mathrm{NaOH}$ and added to the culture medium. The $\mathrm{pH}$ of the medium was set at $\mathrm{pH} 7.4$ with $0.5 \mathrm{~N} \mathrm{HCl}$ and the cells were grown in the presence of $50,000 \mathrm{dpm}\left({ }^{35} \mathrm{~S}\right)$ sulfatide $/ 10 \mathrm{ml}$ in petri dishes for 3 days. Intracellular $\left({ }^{35} \mathrm{~S}\right)$ sulfatide was measured as described previously (19). Free extracellular ${ }^{35} \mathrm{SO}_{4}$ was measured in the nonlipid-soluble, dialyzable fraction in the medium after $72 \mathrm{hr}$ of incubation. All values are expressed as percentage of normal $(100 \%)$. Left: intracellular accumulation of $\left({ }^{35} \mathrm{~S}\right)$ sulfatide per milligram of cell protein; right: free extracellular ${ }^{35} \mathrm{SO}_{4}$ corrected for cell protein; vertical bars: range of values; $N$ : normal; $I_{1}, I_{2}$ : I-cell fibroblasts; $M L D$ : metachromatic leucodystrophy fibroblasts.

${ }^{35} \mathrm{SO}_{4}$-prelabeled fibroblasts in chase experiments $(6,13)$. Concentrates of conditioned culture media from normal fibroblasts (Fig. 4) markedly increased the rate of disappearance of the label through partial correction of the degradation in Hurler, Hunter, and Sanfilippo fibroblasts (Fig. 4). Concentrates from media from I-cell fibroblasts were not able to correct the faulty degradation in any of the three mucopolysaccharidoses.

The defective $\left({ }^{35} \mathrm{SO}_{4}\right)$ MPS degradation in I-cell fibroblasts, however, was corrected by the addition of normal conditioned 


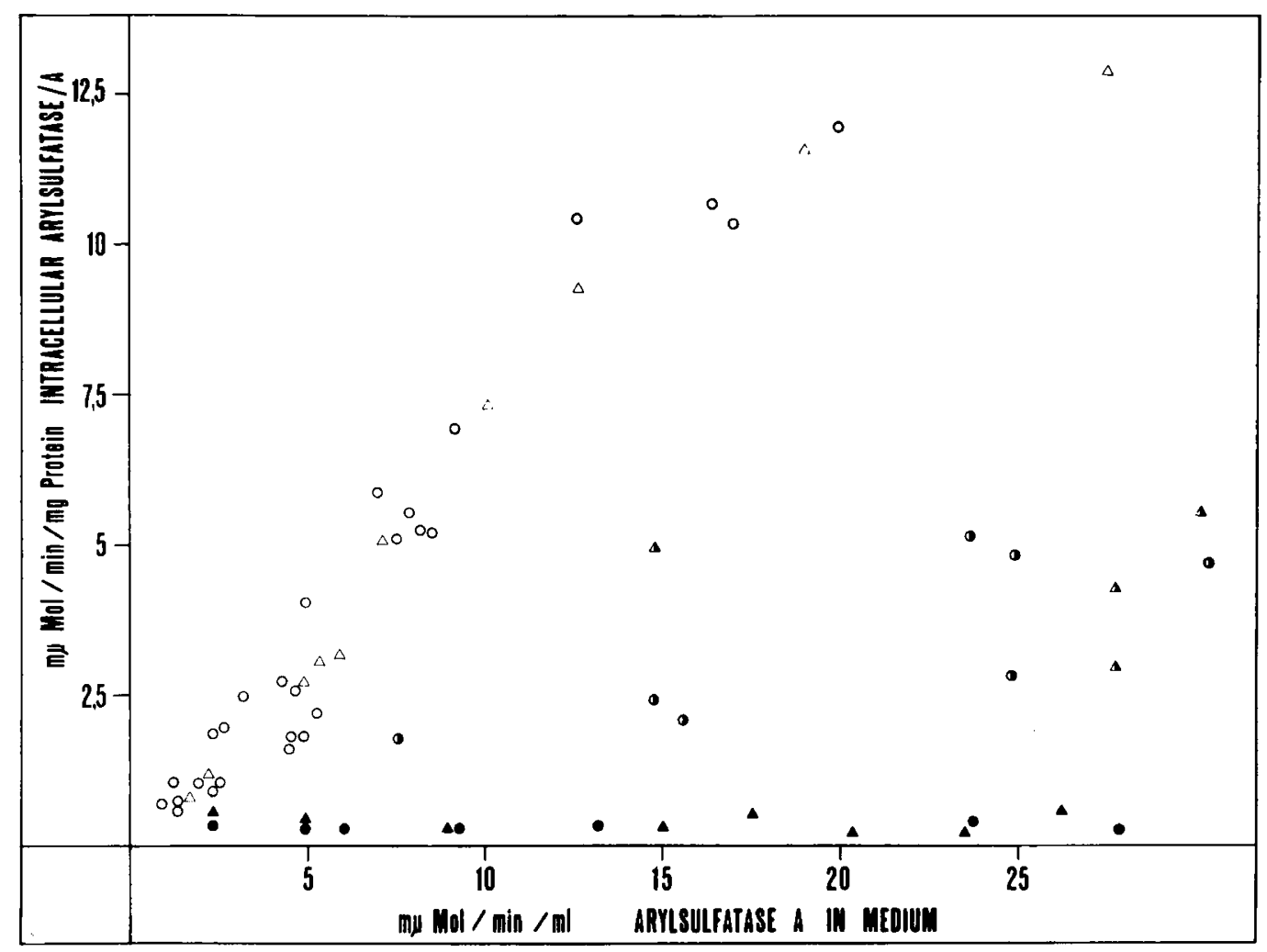

Fig. 3. Enzyme substitution in arylsulfatase A-deficient cells. Arylsulfatase A preparation from normal urine, from urine of two patients with mucolipidosis II, and from urine of their parents was added in increasing activities to medium in which metachromatic leucodystrophy (MLD) fibroblasts and I-cell fibroblasts, respectively, were grown. After a 24-hr incubation the cells were harvested by trypsinization and arylsulfatase A activity was measured in the cells and in the culture medium. $\circ$ : MLD fibroblasts; $\triangle$ : I-cell fibroblasts; $\circ, \triangle$ : substitution with normal arylsulfatase A; •, ^: substitution with mucolipidosis II arylsulfatase A.

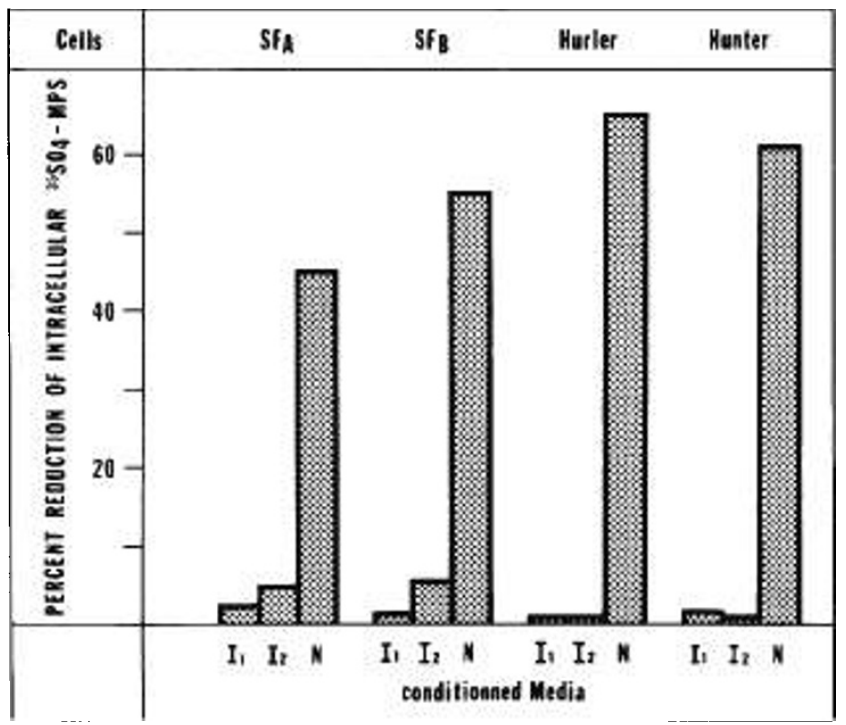

Fig. 4. Failure to correct the faulty $\left({ }^{35} \mathrm{SO}_{4}\right)$ mucopolysaccharide $-(M P S)$ degradation in fibroblasts from patients with mucopolysaccharidosis by conditioned media from I-cell fibroblasts. One milliliter of conditioned, 100 times concentrated media preparations from normal or I-cell fibroblasts respectively, were, added to $6 \mathrm{ml}$ fresh medium containing $5 \mu \mathrm{Ci}$ of carrier-free ${ }^{35} \mathrm{SO}_{4} / \mathrm{ml}$ to culture plates with fibroblasts from Hurler, Hunter, and Sanfilippo patients. Intracellular $\left({ }^{35} \mathrm{SO}_{4}\right)$ MPS per milligram of cell protein was measured after $48 \mathrm{~h}$ of incubation. The results of the test plates were calculated as a percentage of the results in control plates, which received saline instead of media concentrates. The final results were expressed as a percentage reduction of the intracellular $\left({ }^{35} \mathrm{SO}_{4}\right)$ MPS accumulation in the test plates compared with the controls. Source of the conditioned media. $I_{1}, I_{2}$ : two different I-cell strains; $N$ : normal fibroblasts. media concentrates (Fig. 5) partially corrected by the media from Hurler and Sanfilippo A and B fibroblasts. It was not corrected by conditioned media from I-cell fibroblasts.

\section{DISCUSSION}

A multiple deficiency of lysosomal enzymes has been demonstrated in cultured skin fibroblasts by us (12) and others $(11,17)$. Some evidence exists that lysosomal enzyme activities also are decreased in patients' liver, skin $(17,22)$, and leucocytes (17). An important exception this multiple enzyme deficiency in fibroblasts is the apparent normal activity of acid phosphatase and $\beta$-glucosidase $(9,19)$. There is residual enzyme activity of the deficient enzymes. These display normal $\mathrm{pH}$ optimum and heat inactivation characteristics. Thus we have no evidence for a structural abnormality of the metabolic active site. As a consequence of the low intracellular lysosomal enzyme activity we could demonstrate abnormal degradation function of the lysosomes. Both substrates tested, $\left({ }^{35} \mathrm{SO}_{4}\right)$ MPS synthetized by the cells themselves and $\left({ }^{35} \mathrm{~S}\right)$ sulfatide, a lipid added exogenously to the culture medium, are accumulated by the fibroblasts because of defective degradation. However, the block in the degradation of these two compounds is not as complete as in single lysosomal enzyme deficiencies. Increased lysosomal enzyme activities in the culture medium and in the extracellular fluids of patients with mucolipidosis II seems to be a unique explanation for a multiple intracellular lysosomal enzyme deficiency. There seems to be a inverse correlation between intracellular and extracellular enzyme activity. Normal acid phosphatase activity (18) and low normal $\beta$-glucosidase $(9,19)$ activity were found in conditioned culture media and in plasma of patients with mucolipidosis II (19). In preliminary experiments we could show that in every $3 \mathrm{hr}$ as much of the total residual activity of arylsulfatase A appears in the medium of I-cell 


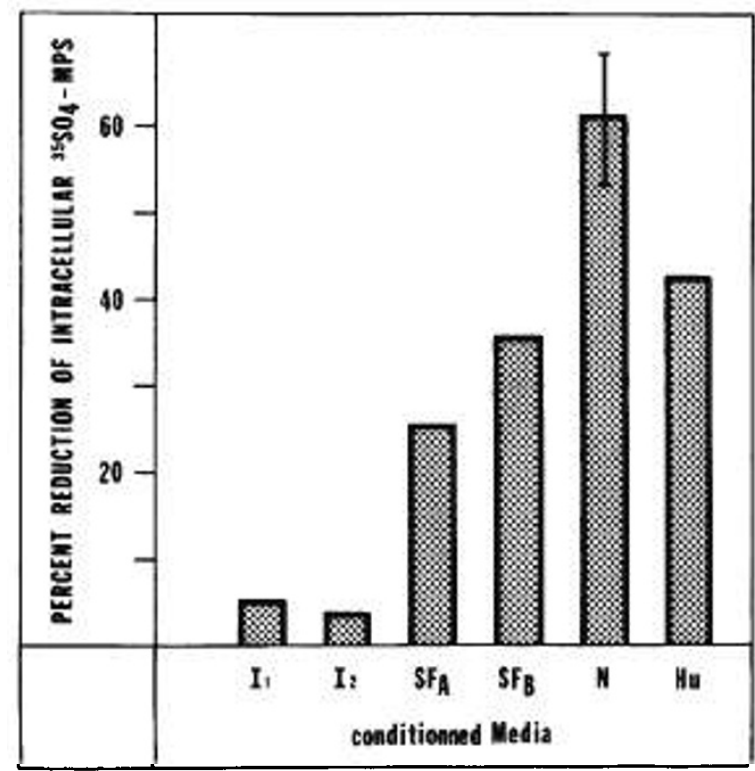

Fig. 5. Correction of the faulty $\left({ }^{35} \mathrm{SO}_{4}\right)$ mucopolysaccharide -(MPS) degradation in I-cell fibroblasts by conditioned media from normal fibroblasts and from fibroblasts from Hurler and Sanfilippo patients. The experimental procedure was the same as in Figure 4 with the exception that I-cell fibroblasts were used as recipients for the conditioned media. Source of the conditioned media. $I_{1}, I_{2}$ : two different I-cell strains; $S F_{A}$ : Sanfilippo type $A$ fibroblasts; $S F_{B}$ : Sanfilippo type $B$ fibroblasts; $H u$ : Hurler fibroblasts; $N$ : normal fibroblasts.

fibroblasts as would appear in the culture medium after 3 days from normal cells. Thus there can be little doubt that the lysosomal enzymes are lost from I-cells in great excess of normal. In vivo this may or may not lead to a functional disturbance of the lysosomes as a consequence of the residual lysosomal activity within the cells. Fibroblasts from obligate heterozygotes also lose lysosomal enzymes but do not show a significant decrease of intracellular lysosomal enzymes and are functionally normal. Since the parents are clinically normal it could be speculated that not presence of increased extracellular lysosomal enzyme activities but decreased intracellular enzyme activities in vivo is responsible for the clinical picture of muclipidosis II. In cultured fibroblasts from patients with metachromatic leucodystrophy (20) and with mucopolysaccharidosis of various types (13) caused by single lysosomal enzyme deficiencies the missing enzyme can be substituted by supplementing this enzyme into the culture medium. It is taken up by pinocytosis and localized in secondary lysosomes as can be shown by electronmicroscopy (4). Arylsulfatase A, MPS-degrading factors, as well as other macromolecules like $\left({ }^{14} \mathrm{C}\right)$ dextran $(19)$, are normally pinocytosed and retained by I-cell fibroblasts and the substitution of enzyme is followed by a correction of the defective lysosomal degradation.

Enzymes prepared from conditioned culture media and/or urine of patients with mucolipidosis II failed to be pinocytosed into enzyme-deficient cells. This observation, first published by Hickman and Neufeld (9) for I-cell $N$-acetyl- $\beta$ galactosaminidase, has now been confirmed for arylsulfatase A. The same mechanism also explains the failure of I-cell media concentrates to correct the defective metabolism of $\left({ }^{35} \mathrm{SO}_{4}\right)$ MPS in mucopolysaccharidoses.

As it has been suggested by Paigen (14), enzymes not only can be structurally abnormal in respect to inactivation of the active site, but also in regard to a retention or intracellular localization unit, leaving the enzyme fully active. The structural alteration could possibly be a carbohydrate unit of the lysosomal enzyme glycoproteins $(7,23)$. Such alteration must be small since preliminary data did not reveal significant differences between I-cell and normal arylsulfatase A regarding density gradient ultracentrifugation and isoelectrofocusing (19). We think that the loss of lysosomal enzymes into the extracellular fluids or culture medium is closely related to the fact that they are not taken up into fibroblasts from the medium. The same localization defect that makes them leave the cells may be responsible for the fact that they can not re-enter the cells. To explain the multiplicity of the enzyme defect we assume that the structural change occurs at a part common to all of the enzyme molecules and which is under genetic control independent of the gene which regulates the synthesis of the active site. In this respect it may be relevant that Fishmann et al. (5) could demonstrate a partial deficiency of a glycosyltransferase in two out three fibroblast lines of patient with mucolipidosis II.

\section{SUMMARY}

A marked decrease in the activity of arylsulfatase A and $B$, both hexosaminidases, $\alpha$-fucosidase, and $\beta$-galactosidase, was found in fibroblast lines from four patients with I-cell disease.

The activities of acid phosphatase and of nonlysosomal enzymes were found to be normal. The $\mathrm{pH}$ optimum and thermolability of the residual activity of arylsulfatase $A$ and $N$-acetyl- $\beta$-galactosaminidase were normal. The activities of arylsulfatase $\mathrm{A}$ and $\mathrm{B}$, both hexosaminidases, and of $\alpha$-fucosidase in the conditioned culture media from all four cell strains were found to be $2-10$ times higher than normal. Thus, the decrease in the activity of intracellular lysosomal enzymes was considered to be the consequence of a loss of enzymes into the extracellular space.

The rate of degradation of $\left({ }^{35} \mathrm{SO}_{4}\right)$ MPS and of $\left({ }^{35} \mathrm{~S}\right)$ sulfatide was abnormally low in I-cell fibroblasts, which indicated that the function of the lysosomes was affected by this loss of enzymes.

Increased cell death as a source of extracellular lysosomal enzyme activity could be excluded. No evidence was found which indicated loss of lysosomal enzymes on the level of the secondary lysosomes. Substitution of the enzyme-deficient cells with normal arylsulfatase $A$ was possible and the enzyme was retained normally, but substitution with arylsulfatase A from urine of a patient with I-cell disease failed. Substitution experiments with arylsulfatase A from urine of obligate heterozygotes gave intermediate correction.

Correction of the faulty $\left({ }^{35} \mathrm{SO}_{4}\right)$ MPS was achieved by conditioned media fractions from normal fibroblasts but not with conditioned media fractions from patient fibroblasts.

The results suggest a loss of lysosomal enzymes from the cells, before the entry into secondary lysosomes and a failure of these enzymes to re-enter the cells. A theory is presented to explain both the loss of enzymes and the fact that they are unable to re-enter the cells.

\section{REFERENCES AND NOTES}

1. Baggiolini, M., Hirsch, J. G., and De Duve, C.: Resolution of granules from rabbit heterophil leukocytes into distinct populations by zonal sedimentation. J. Cell Biol., 40: 529 (1969).

2. Baum, H., Dogson, K. S., and Spencer, B.: The assay of arylsulphatase $A$ and $B$ in human urine. Clin. Chem. Acta, 4: 453 (1959).

3. Bergmeyer, H. U. (Editor): Methoden der enzymatischen Analyse (Weihnheim, 1962).

4. Bischoff, A., et al: : Demonstration of substituted arylsulfatase $A$ in fibroblasts by electron microscopy (to be published).

5. Fishmann, P., Wiesmann, U. N., and Herschkowitz, N.: Activities of sugar nucleotides: Gly coprotein galactosyl and sialytransferase in human cultured fibroblasts (to be published).

6. Fratantoni, J. C., Hall, C. W., and Neufeld, E. F.: The defect in Hurler's and Hunter's syndromes: Faulty degradation of mucopolysaccharide. Proc. Nat. Acad. Sci. U. S. A., 60: 699 (1968).

7. Goldstone, A., and Koenig, A. H.: Lysosomal hydrolases as glycoproteins. Life Sci., 9: 1341 (1970).

8. Herschkowitz, N., Mc Khann, G. M., Saxena, A., and Shooter, E. M.: Characterization of sulfatide containing lipoproteins in rat brain. J. Neurochem., 15: 1181 (1968). 
9. Hickman, S., and Neufeld, E. F.: A hypothesis for I-cell disease: Defective hydrolases that do not enter lysosomes. Biochem. Biophys. Res. Commun., 49: 992 (1972).

10. Leroy, J. G., and De Mars, R. I.: Mutant enzymatic and cytological phenotypes in cultured human fibroblasts. Science, 157: 804, (1967).

11. Lightbody, J., Wiesmann, U., Hadorn, B., and Herschkowitz, N.: I-cell disease: Multiple lysosomal enzyme defect. Lancet, $i$ : 451 (1971).

12. Lowry, O. H., Rosebrough, N. J., Farr, A. L., and Randall, R. J. Protein measurement with the Folin phenol reagent. J. Biol. Chem., 193: 795 (1951).

13. Neufeld, E. F., and Cantz, M. U.: Corrective factors for inborn errors of mucopolysaccharide metabolism. Ann. N. Y. Acad. Sci., 72: 580 (1971).

14. Paigen, K.: In: M. Recheigl: Enzyme Synthesis and Degradation in Mammalian Systems, pp. 1-46 (Karger, Basel 1971).

15. Tondeur, M., Vamos-Hurwitz, E., Mockel-Pohl, S., Demeure, J. P.,

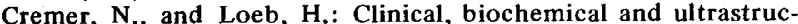
tural studies in cases of chondrodystrophy presenting the I-cell phenotype in tissue culture. J. Pediat., 79: 366 (1971).

16. Van Hoof, F., and Hers, H. G.: The abnormalities of lysosomal enzymes in mucopolysaccharidoses. Eur. J. Biochem., 7: 34 (1968).

17. Walbaum, R., Dehaene, P., Scharfman, W., Farriaux, J. P., Tondeur, M., Vamos-Hurwitz, E., Kint, J. A., and Van Hoof, F.: La mucolipidose de type II (I-cell disease). Arch. Franc. Pédiat.,
30: 577 (1973)

18. Wiesmann, U. N., Lightbody, J., Vassella, F., and Herschkowitz, N, N.: Multiple lysosomal enzyme deficiency due to enzyme leakage? New Engl, J. Med., 284: 109 (1971).

19. Wiesmann, U. N., Eto, Y., and Herschkowitz, N: To be published.

20. Wiesmann, U. N., Rossi, E. E., and Herschkowitz, N. N.: Correction of the defective sulfatide degradation in cultured fibroblasts from patients with MLD. Acta Paediat. Scand., 61: 296 (1972).

21. Wiesmann, U. N., Vassella, F., and Herschkowitz, N.: I-cell disease: Leakage of lysosomal enzymes into extracellular fluids. New Engl. J. Med., 28:5: 1090 (1971).

22. Wiesmann, U. N., Vassella, F., and Herschkowitz, N. N.: Mucolipodosis II (I-cell disease): A clinical and biochemical study. Acta Paediat. Scand., 63: 9 (1973).

23. Winterburn, P. J., and Phelps, C. F.: The significance of glycosylated proteins. Nature, 236: 147 (1972).

24. We thank Dr. Loeb, Brussels, and Dr. E. E. Neufeld, National Institutes of Health, Bethesda, Md., for supplying us with cultures from their patients.

25. This work was supported by Swiss National Foundation Grants nos. 3.407.70, 3.697.71, and 5072.3 and by the Hochschulstiftung Bern.

26. Requests for reprints should be addressed to: U. N. Wiesmann M.D., Department of Pediatrics, Division of Cell Biology and Neurochemistry, University of Berne, Berne, Switzerland.

27. Accepted for publication July 2, 1974.
Amniocentesis amniotic fluid cells fetal calf serum

\title{
Amniotic Fluid Cell Culture I. Experimental Design for Evaluating Cell Culture Variables: Determination of Optimal Fetal Calf Serum Concentration
}

\author{
JEANETTE S. FELIX, RICHARD A. DOHERTY,(24) HENRY T. DAVIS, AND SUSAN C. RIDGE \\ Departments of Pediatrics, Radiation Biology/Biophysics, Divisions of Genetics, Biostatistics, \\ University of Rochester School of Medicine and Dentistry, Rochester, New York, USA
}

\section{Extract}

We have developed a randomized, multivariable block design for quantitative evaluation of conditions for amniotic fluid (AF) cell attachment to culture surface and subsequent growth rate. We report the use of this method to determine optimal fetal calf serum (FCS) concentration in the culture medium. The AF cell growth, in the form of discrete colonies, was scored by counting the number of colonies and measuring their diameters. A two-way analysis of variance of the preliminary experiment data $(5-30 \%$ FCS $)$ demonstrated a significant difference among AF cells grown at different percentages of FCS $(P<\mathbf{0 . 0 0 0 5})$. From a studentized range analysis we concluded that $5 \%$ FCS is inferior to higher percentages. No difference was demonstrated among 15-30\%
FCS. Based on these data, a supplementary experiment was planned to compare 10 and $15 \%$ FCS. The $15 \%$ FCS yielded at least 0.31 colonies $/ \mathrm{ml}$ AF more than did $10 \%$ FCS. We conclude that $15 \%$ FCS is sufficient for AF cell culture using our technique. Close agreement of the estimates of standard deviation of the preliminary and supplementary experiments (7.38 and 7.25) indicates that the assumptions required for our experimental design are correct and that our technical procedures are highly reproducible.

A larger series of 76 AF specimens was used to correlate patient data with AF cell growth. We have shown that AF cell growth is independent of: $(l)$ gestational age between 11 and 24 weeks; (2) maternal age between 14 and 42 years; (3) maternal ethnic group. A mean of 6 colonies/ml AF was obtained. 